\title{
LIMITES CONVENCIONAIS À COMPETÊNCIA DA AUTORIDADE ELEITORAL BRASILEIRA
}

\author{
Conventional Limits to the Competence of the Brazilian Electoral Authority
}

\section{(iD) Amanda Guimarães da Cunha}

\author{
D Eneida Desiree Salgado
}

Resumo: A governança eleitoral no sistema jurídico brasileiro é exercida de forma concentrada pela autoridade eleitoral, a qual cumula as funções administrativas, jurisdicionais, consultivas e, ainda, uma autorreconhecida competência normativa. As decisões, no entanto, são tomadas por agentes que não têm uma formação própria voltada à atuação nas lides eleitorais, sendo "emprestadas" dos outros ramos do Poder Judiciário, bem como da advocacia. Além disso, não têm quaisquer impedimentos para atuar numa ou outra esfera judicial, e até mesmo para atuar na mesma lide em diferentes momentos processuais e recursais. Um contexto ímpar no direito brasileiro, que permite que o contencioso eleitoral transcorra de forma contrária à ordem constitucional e convencional vigente. Dentre as numerosas problemáticas derivadas deste cenário, neste trabalho optou-se por analisá-lo a partir de uma das garantias mais fundamentais do devido processo: a de imparcialidade para julgamento. Para tanto, recorreu-se aos parâmetros advindos do regime de proteção convencional previsto no art. $8^{\circ}$ da Convenção Americana de Direitos Humanos, nos termos e alcance definidos pela Corte Interamericana. Conclui-se que a ampla competência da autoridade eleitoral vai de encontro à garantia de imparcialidade para julgamento. Diante disso, estas autoridades devem, tendo em vista o dever de observância aos padrões interpretativos convencionais e de realizar o controle de convencionalidade de ofício, adequarem-se ao instituto do impedimento.

Palavras-chave: Justiça Eleitoral. Dever de imparcialidade. Devido processo convencional. Controle de convencionalidade. Impedimento da autoridade eleitoral.

\begin{abstract}
Electoral governance in the Brazilian legal system is exercised in a concentrated manner by the electoral authority, which combines administrative, jurisdictional, consultative functions, and a self-recognized normative competence. However, decisions are made by agents untrained in acting as electoral subjects, "borrowed" from other branches of the Judiciary and the legal system. In addition, they have no impediments to act in one or another judicial sphere and even to act in the same lawsuit at different procedural and appeals. This is a unique feature of Brazilian law, allowing electoral litigation to run contrary to the current constitutional and conventional order. Among the numerous issues arising from this scenario, we chose to analyze one of the most fundamental guarantees of due process: judge's impartiality. We used the parameters arising from the conventional protection regime provided for in art. 8 of the American Convention on Human Rights, under the terms and scope defined by the Inter-American Court. It is concluded that the broad competence of the electoral authority goes against the guarantee of judge's impartiality. Therefore, these authorities must adapt to the institute of the inability to proceed, in view of the duty of observing conventional interpretative standards and to do the conventionality control ex officio.
\end{abstract}

Keywords: Electoral court. Duty of impartiality. Due conventional process. Conventionality control. Electoral authority's inability to proceed.

Artigo recebido em 6 abr. 2021 e aprovado em 7 jul. 2021

Editor responsável: Luiz Magno Pinto Bastos Junior

DOI: https://doi.org/10.53323/resenhaeleitoral.v25i1.138

Resenha Eleitoral, Florianópolis, v. 25, n. 1, p. 59-84, jan./jun. 2021 


\section{Introdução}

A imparcialidade na tomada de decisão judicial erige-se, atualmente, como uma das garantias mais importantes do devido processo legal a ser resgatada. A crescente demonização da política, e o surgimento de movimentos antidemocráticos que colocam sobre si o manto da luta contra a corrupção, como o "lavajatismo" e o "fichalimpismo", acabam por deslocar o sentimento de representação popular ao Poder Judiciário, na falsa crença de que ele deve, e pode, "depurá-la", ao custo da relativização das garantias processuais e com restrições inadmissíveis aos direitos políticos fundamentais. E esse tem, por sua vez e oportunamente, tomado para si um papel protagonista que não lhe foi conferido, tampouco lhe é legítimo, gerando uma onda de judicialização que afeta todo o sistema jurídico.

$\mathrm{Na}$ seara eleitoral isso ganha uma proporção ainda mais problemática, tendo em vista que a governança é exercida pela mesma autoridade. A forma com que se estruturou a Justiça Eleitoral, em um impulso autoritário e centralizador no governo provisório de Getúlio Vargas, concentrou as funções administrativas, consultivas e jurisdicionais nas mãos da autoridade eleitoral. Não suficiente, esta se autoarvorou uma competência normativa sem qualquer respaldo legal ou constitucional, cujo exemplo mais sintomático são as polêmicas resoluções (SALGADO, 2016, p. 186). Uma estrutura judicial suigeneris que parece repelir qualquer forma de check and balances, tendo em vista que são as mesmas autoridades que determinarão, em grande medida, as regras a serem seguidas e julgarão, em muitos casos, os recursos judiciais contra suas próprias decisões.

Além disso, as pessoas que ocupam o lugar de decisão nesta engrenagem não têm uma carreira própria, independente e voltada à atuação eleitoral. Desde o primeiro grau até o Tribunal Superior Eleitoral (TSE), elas são "emprestadas" das outras esferas judiciais, inclusive estaduais, transitando entre uma e outra, sem que haja quaisquer impedimentos em suas atuações. Os Tribunais Regionais Eleitorais (TRE) e o TSE são compostos, ainda, por advogados e advogadas indicadas pelos próprios tribunais e por escolha da Presidência da República, sem qualquer limitação para atuação na advocacia quando deixam de fazer parte das cortes, bem como enquanto ainda estão lá, nos outros ramos da justiça ${ }^{1}$.

\footnotetext{
${ }^{1}$ É digno de nota que tramita no Senado Federal a PEC 70/2015 que pleiteia justamente o impedimento destas autoridades em atuarem como advogados e advogadas, enquanto
} 
A situação chega a ser tão problemática que, além de não haver quaisquer óbices ou impedimentos para atuação destas autoridades, quando atuam numa ou outra esfera judicial, a Súmula no 72 do Supremo Tribunal Federal ${ }^{2}$ (STF) autoriza expressamente que seus Ministros e Ministras possam participar de julgamentos de processos nos quais atuaram preliminarmente na Corte Eleitoral. Esse compartilhamento de autoridades não preenche os requisitos mínimos da menos ambiciosa noção de Estado de Direito.

Esse quadro foge às regras de impedimento no direito brasileiro, que proíbe expressamente, para todos os demais ramos, uma autoridade judiciária de julgar recurso contra a sua própria decisão ${ }^{3}$, fora obviamente das hipóteses de retratação, o que permite concluir, sem qualquer acautelamento, que há uma blindagem das decisões eleitorais (GRESTA, 2019, p. 127-130).

A partir disso, permite-se, portanto, numa instituição fundamental para o pleno funcionamento da democracia, que as decisões não se deem de forma independente e imparcial. O clássico dilema grego sobre governo das pessoas e governo das leis já denunciava a natural parcialidade do ser humano pelas suas paixões congênitas, o que foi (deveria) ter sido superada pelo surgimento dos Estados constitucionais e de Direito (BOBBIO, 2000, p. 165-166). Curiosamente, é justamente na arena jurídica diretamente sujeita às paixões políticas que essa tônica perdura.

A necessidade de construção de uma atuação jurisdicional independente e imparcial pela Justiça Eleitoral está pendente desde sua criação em 1932. O entusiasmo e expectativas daquela época com sua criação não correspondiam com a realidade e os interesses detrás dos discursos moralizantes que propositadamente a mantiveram sobre controle dos governantes (ZULINI, 2019).

investidos da autoridade eleitoral. Disponível em: https://www25.senado.leg.br/web/atividade/materias/-/materia/121684.

${ }^{2}$ No julgamento de questão constitucional, vinculada à decisão do Tribunal Superior Eleitoral, não estão impedidos os Ministros do Supremo Tribunal Federal que ali tenham funcionado no mesmo processo, ou no processo originário.

${ }^{3}$ O Código de Processo Civil impede a atuação da autoridade judiciária em quaisquer processos em que este tenha conhecido e proferido decisão em outro grau de jurisdição (Art. 144, II). O equivalente no Código de Processo Penal encontra-se no art. 252, III. 
Esse sentimento hoje pode ser facilmente identificado pelos elogios feitos à sua atuação administrativa e de organização das eleições (com justo motivo). Entretanto, a estrutura de cumulação destas competências com a jurisdicional, a forma de escolha e compartilhamento das autoridades eleitorais e de ausência de regulamentações sobre suas atuações persiste desde essa época ditatorial, sem que se tenha tido coragem de passá-la a limpo. Ainda menos, de redemocratizá-la. A própria Súmula no 72 é fruto de período autoritário, tendo sido editada em $1963^{4}$, sem que se tenha feito inclusive quaisquer análises de recepção com a Constituição de 1988.

Com um panorama destes, não se pode esperar obter, realmente, decisões consistentes e fundamentais para a administração da justiça, com a consequente segurança jurídica almejada para quem participa da disputa na arena eleitoral.

Para readequar toda essa estrutura, buscando compatibilizá-la com ordem constitucional e convencional vigente, é necessário enfrentar uma série de variáveis e projetar alguns cenários. Propõe-se, neste estudo, iniciar essa tarefa pela análise da ampla competência jurisdicional da autoridade eleitoral a partir da garantia de imparcialidade para julgamento. Considera-se este um importante ponto de partida, tendo em vista que não existe justiça, nem democracia, nem liberdade e direitos fundamentais, nem o próprio devido processo se os órgãos pertencentes ao Poder Judiciário, que julgam e executam o que é julgado, não são, absolutamente, e desde qualquer ponto de vista, imparciais (GUERRERO PALOMARES, 2009, p. 28).

Para levar a cabo essa tarefa, considerando que esta garantia não está prevista expressamente na Constituição, embora derive da regra do próprio devido processo legal, dentre outras, propõe-se que isso seja feito de uma perspectiva não usual, impulsionada pela cláusula de abertura: a partir dos parâmetros advindos do Sistema Interamericano de Direitos Humanos (SIDH), notadamente daqueles que derivam das garantias judiciais previstas no art. 8o da Convenção Americana de Direitos Humanos $(\mathrm{CADH})$, a partir da leitura feita pela Corte Interamericana de Direitos Humanos (CorteIDH).

\footnotetext{
${ }^{4}$ Julgado de 13/12/1963, tendo como base o art. 97, II, e 200 da Constituição de 1946 e o art. 87 do Regimento do STF de 1940. Disponível em: http://www.stf.jus.br/portal/ jurisprudencia/listarJurisprudencia.asp?s1=72.NUME. $\% 20 \mathrm{NAO} \% 20$ S.FLSV.\&base=baseSumulas.
} 
Embora se reconheça uma recorrente resistência à incorporação dos tratados internacionais à ordem jurídica interna, com o consequente desrespeito aos compromissos assumidos pelo Estado brasileiro ao aderir voluntariamente ao SIDH, o dever de observância aos padrões convencionais ganha fôlego com a retomada, em especial, do debate sobre o impacto dos direitos humanos no regime dos direitos políticos fundamentais em razão da discussão sobre a inconvencionalidade da Lei Complementar n ${ }^{\circ}$ 135/2010, a chamada Lei da Ficha Limpa e sobre a possibilidade de candidaturas avulsas que tramita perante o STF.

Além disso, tais obrigações possuem, tomando-se como referência um critério hierárquico de normas, status supralegal no ordenamento jurídico brasileiro, conforme já decidiu o $\mathrm{STF}^{5}$, quando situou a $\mathrm{CADH}$ acima de toda legislação infraconstitucional, inclusive, frisa-se, de toda legislação eleitoral. As autoridades judiciais nacionais estão vinculadas, ainda, ao dever de observância dos parâmetros advindos do SIDH, diante da obrigação de exercerem o controle de convencionalidade de ofício (FERRER MAC-GREGOR, 2011, p. 563-565; CUNHA, BASTOS JR, 2021, p. 39-49)

Sendo assim, a fim de atender o objetivo geral estabelecido, num primeiro momento será exposta brevemente a forma de investidura da autoridade eleitoral brasileira, desde o primeiro grau até o TSE, bem como os limites para o exercício da jurisdição, com algumas breves ponderações de importância para a análise que aqui se propõe. No segundo tópico serão apresentados os contornos acerca da garantia convencional de imparcialidade para julgamento, a fim de verificar a compatibilidade, ou não, destas diretrizes à amplitude da competência da autoridade eleitoral brasileira.

\section{A autoridade eleitoral no direito brasileiro}

Para início da análise que se pretende, será delineado de forma breve como se compõe a estrutura da justiça eleitoral, no que diz respeito à autoridade judicial, desde o primeiro grau de jurisdição até os tribunais, bem como e em especial a amplitude da competência destas autoridades, com a exposição de alguns exemplos que ajudam a dimensionar o problema que aqui se propôs a começar a enfrentar.

Inicialmente, cabe frisar novamente que, diferente da estrutura de servidores da Justiça Eleitoral, leia-se técnicos e analistas judiciários, não

${ }^{5}$ Vide RE n. 466.343-1/SP e HC n. 87.585/TO. 
existe uma carreira de ingresso e de formação própria para a autoridade eleitoral. Conforme apontado brevemente, embora com algumas modificações ao longo do tempo no que diz respeito às instituições e a quantidade de autoridades vindas de cada uma delas, essa lógica persiste desde sua criação em $1932^{6}$.

A construção de uma magistratura concursada e independente não ganhou espaço já naquela época, quando havia supervisão da atividade jurisdicional pelos poderes constituídos, o que chegou a ser descrito como um "poder judiciário político" (ZULINI, 2019, p. 453-468).

O Código Eleitoral (Lei no 4.737/1965) estabelece, em seu artigo 32, que a autoridade eleitoral na instância ordinária provém da justiça comum estadual ${ }^{7}$. Ela será responsável, em linhas gerais, por organizar as eleições municipais, verificar as condições dos eleitores, exercer o poder de polícia e dirigir os processos eleitorais administrativos e contenciosos ${ }^{8}$. Ou seja, tem competência polivalente (PEREIRA, 2015, p. 90-99), cabendo a esta mesma autoridade, por exemplo, julgar as ações e representações judiciais baseadas nos próprios atos realizados quando investida do poder de polícia, competência esta ao arrepio da Constituição, conferida por meio de Resolução ${ }^{9}$ e não por previsão legal.

Já no que diz respeito aos Tribunais Regionais, sua formação está prevista na Constituição de 1988. Segundo o delimitado pelo art. 120, os TREs serão compostos por duas autoridades judiciais escolhidas dentre as desembargadoras e desembargadores do Tribunal de justiça do estado respectivo; de outras duas dentre aquelas de Direito do mesmo Tribunal, indicadas por este; de uma do Tribunal Regional Federal com sede na Capital do Estado ou no Distrito Federal e, se não houver, de uma autoridade federal escolhida, em qualquer caso, pelo TRF respectivo; e de dois membros da advocacia, escolhidos dentre seis, a partir de duas listas tríplices, indicados pelo Tribunal de Justiça, e nomeados pelo Presidente da República. Por imposição legal, o TRE deverá definir quem será seu presidente e vice dentre os desembargadores ( $\int 2^{\circ}$ do art. 120).

\footnotetext{
${ }^{6}$ Vide art. 9, 21ํ e 30º do Código Eleitoral de 1932.

${ }^{7}$ Vide art. 32 do Código Eleitoral de 1965.

${ }^{8}$ Vide art. 35 do Código Eleitoral de 1965.

${ }^{9}$ Vide art. 17 da Resolução no 20.951/2000 do TSE.
} 
Com relação à competência, o Tribunal também cumula as funções administrativas referentes às eleições e a atuação contenciosa, estando estas regulamentadas nos art. 29 e 30 do CE.

Da miscelânea de órgãos e instituições na composição dos TRE, e da cumulação de competências, decorre uma série de problematizações. De plano, pode-se fazer a seguinte constatação: não existe nenhum óbice para que aquela mesma autoridade eleitoral que ficou à frente das eleições municipais possa vir a compor a estrutura do TRE de seu estado e, oportunamente, julgar os próprios processos originários que estejam agora em sede recursal, ainda que o rodízio entre ocupantes do judiciário e a rapidez dos julgamentos dos processos torne essa possibilidade remota.

Não existem, tampouco, restrições no que diz respeito a impedimentos para quando estas autoridades voltem a atuar nas justiças comuns de onde vieram e recebam, porventura, processos conduzidos por advogados ou advogadas que com eles compuseram a corte e vice-versa. Também não existem limitações ou quaisquer tempos de "quarentena" para membros da magistratura e da advocacia, podendo estes últimos, tão cessada suas atuações, voltarem a atuar perante a própria Corte da qual fizeram parte. Aliás, enquanto lá estiverem, podem continuar advogando nas outras esferas.

Chegando ao ápice da estrutura da Justiça Eleitoral, as incongruências persistem. O Tribunal Superior Eleitoral, pelo artigo 119 constitucional, é composto mediante eleição, por voto secreto: de três autoridades do STF, entre os quais deverão ser escolhidos seu presidente e vice, e de duas do STJ; e, por nomeação da Presidência da República, de dois membros da advocacia, indicados em duas listas tríplices STF.

Suas competências administrativas e jurisdicionais estão previstas nos art. 22 e 23 do CE, sem mencionar as normativas autoconcedidas, já mencionadas. Aqui, além de se repetir todas as problemáticas já apontadas e inerentes a essa estrutura, ainda se depara com uma autorização expressa da Suprema Corte do país para atuação de seus Ministros e Ministras diante das lides eleitorais.

Conforme visto de forma introdutória, a Súmula no 72 permite expressamente que as então autoridades constitucionais julguem os mesmos processos que analisaram quando estiveram investidos da autoridade eleitoral. Tal súmula, editada em 1963, nunca foi revisitada pelo STF diretamente. Entretanto, na Ação por Descumprimento de Preceito Fundamental no 144 
do Distrito Federal, o tema do impedimento destas autoridades foi tratado de forma tangencial.

Nesta ADPF, a Associação dos Magistrados Brasileiros (AMB) pleiteava que não fosse exigido o trânsito em julgado para as decisões que reconhecessem as inelegibilidades das alíneas "d", "e" e "h" do inciso I do art. 1, do art. 15², da Lei Complementar $n^{\circ}$ 64/1990, bem como que também fosse desconsiderada a exigência de que as contas rejeitadas por irregularidade insanável ou decisão irrecorrível do órgão competente tivessem que ser apreciadas pelo Poder Judiciário para incidência da alínea "g", também do mesmo inciso I do art. $1^{\circ}$ da LC nº 64/1990. A AMB argumentou que estes fatores impediam que a Justiça Eleitoral utilizasse estes parâmetros para fins de investigação sobre a vida pregressa de candidatos, prevista no art. 14, par. 9², da CR/1988, para fins de análise (e indeferimento) do pedido de registro de candidatura.

O pedido ia de encontro ao estabelecido pelo TSE em sua Súmula $\mathrm{n}^{\circ} 13$, que considerava que o parágrafo $9^{\circ}$ do artigo 14 da Constituição não era autoaplicável, ou seja, dependia das previsões da Lei Complementar. Esse entendimento foi replicado em alguns julgados posteriores, dos quais haviam participado cinco Ministros do STF que agora estavam julgando a ADPF em questão (Min. Marco Aurélio, Cezar Peluso, Carlos Ayres Britto, Joaquim Barbosa e Eros Grau). Em razão disso, foi suscitado de forma preliminar que estas autoridades não teriam condições jurídico-legais para participar do julgamento pela AMB. O Min. Carlos Britto, ainda, participou diretamente na ADPF, prestando informações na condição de presidente do TSE.

Por unanimidade, os então Ministros do STF rejeitaram a preliminar, alegando que os institutos de impedimento e suspeição não são aplicáveis ao processo de controle normativo abstrato como no concreto, quando as demandas de índole constitucional foram oriundas do TSE. Além dos "impedidos", participaram do julgamento também os Min. Celso de Mello, Ellen Gracie, Ricardo Lewandovski, Carmen Lúcia e Menezes Direito.

Entretanto, paradoxalmente, já houve casos em que Ministros se deram por impedidos por terem atuado na causa de alguma forma, como quando o Min. Dias Toffoli se afastou do julgamento do pedido de extradição no 1.085 e Mandado de Segurança no 27.875/DF, referentes a Cesare Battisti, por ter atuado preliminarmente como Advogado Geral da União quando o refúgio político lhe foi concedido. 
Diante disso, não restam dúvidas de que há nitidamente a intenção de se resguardar uma estrutura parcial na mais alta corte de justiça do país, no que diz respeito às lides eleitorais, com a blindagem das autoridades eleitorais que ora compõem a Corte Constitucional.

Com este breve apanhado, pretende-se estabelecer como premissa que a falta de estrutura e formação próprias da autoridade eleitoral e de limites claros sobre suas atuações colocam em xeque a imparcialidade de suas decisões, o que explica, em boa parte, a falta de uniformidade, de clareza e de consistência constitucional e convencional de seus pronunciamentos.

E para o início dessa necessária desconstrução, essencial para que se sistematize e se permita a evolução do Direito Eleitoral como ciência e sua aplicação como prática democrática, destinada a garantir segurança jurídica e contribuir com a vigência do Estado de Direito (ÁLVAREZ GONZÁLEZ apud CIENFUEGOS SALGADO; CIFUENTES VARGAS, 2009, p. 37), bem como para preservar a legitimidade do pleito (ZILIO, 2020, p. 85), que se debruçara sobre a análise da ampla competência jurisdicional da autoridade eleitoral a partir da garantia convencional (e constitucional) da imparcialidade para julgamento.

\section{A garantia convencional de imparcialidade para julgamento}

O artigo $8^{\circ}$ da Convenção Americana de Direitos Humanos prevê as regras do devido processo legal no Sistema Interamericano a serem observadas pelos Estados em seus ordenamentos jurídicos internos. Em seu inciso primeiro, há a previsão das garantias mínimas de todos os processos a que uma pessoa pode ser submetida pelo Estado, no exercício de sua jurisdição. Já no inciso segundo são estipuladas regras mínimas a serem observadas, em princípio, em proteção a todas as pessoas acusadas em processos penais.

\section{Segundo a CADH:}

8.1 Toda pessoa tem direito a ser ouvida, com as devidas garantias e dentro de um prazo razoável, por um juízo ou tribunal competente, independente e imparcial, estabelecido anteriormente por lei, na apuração de qualquer acusação penal formulada contra ela, ou para que se determinem seus direitos ou obrigações de natureza civil, trabalhista, fiscal ou de qualquer outra natureza (grifo nosso). 
Ao desenvolver o âmbito de aplicação desta garantia nos casos contenciosos levados à sua apreciação, preliminarmente a CorteIDH fixou que o direito a ser julgado por uma autoridade ou tribunal imparcial é uma garantia fundamental do devido processo, a qual implica no dever de estes conduzirem um julgamento com a maior objetividade, inspirando a confiança necessária às partes do caso e aos cidadãos em uma sociedade democrática (CORTEIDH, 2004, Caso Herrera Ulloa Vs Costa Rica, S 171) ${ }^{10}$.

Invocando precedentes do Tribunal Europeu de Direitos Humanos (TEDH) (CORTEIDH, 2004, Caso Herrera Ulloa Vs Costa Rica, nota de rodapé n⿳ 119), no que é conhecido como diálogo entre cortes, estabeleceu dois aspectos decorrentes desta garantia: um objetivo e outro subjetivo (SALMÓN; BLANCO, 2012, p. 138).

Segundo seus termos:

Em primeiro lugar, o tribunal deve estar subjetivamente livre de preconceitos pessoais. Em segundo lugar, deve também ser imparcial de um ponto de vista objetivo, isto é, deve oferecer garantias suficientes para que não haja dúvidas legítimas a esse respeito. $\mathrm{Na}$ análise objetiva, deve-se verificar se, além do comportamento pessoal dos juízes, existem fatos que podem levantar dúvidas quanto à sua imparcialidade. Nesse sentido, até as aparências podem ter alguma importância. O que está em jogo é a confiança que os tribunais devem inspirar aos cidadãos de uma sociedade democrática e, sobretudo, às partes em causa (CORTEIDH, 2004, Caso Herrera Ulloa Vs Costa Rica, \$170) ${ }^{11}$.

10 "La Corte considera que el derecho a ser juzgado por un juez o tribunal imparcial es una garantía fundamental del debido proceso. Es decir, se debe garantizar que el juez o tribunal en el ejercicio de su función como juzgador cuente con la mayor objetividad para enfrentar el juicio. Esto permite a su vez, que los tribunales inspiren la confianza necesaria a las partes en el caso, así como a los ciudadanos en una sociedad democrática." (Tradução nossa).

11 "Primero, el tribunal debe carecer, de una manera subjetiva, de prejuicio personal. Segundo, también debe ser imparcial desde un punto de vista objetivo, es decir, debe ofrecer garantías suficientes para que no haya duda legitima al respecto. Bajo el análisis objetivo, se debe determinar si, aparte del comportamiento personal de los jueces, hay hechos averiguables que podrán suscitar dudas respecto de su imparcialidad. En este sentido, hasta las apariencias podrán tener cierta importancia. Lo que está en juego es la confianza que deben inspirar los tribunales a los ciudadanos en una sociedad democrática y, sobre todo, en las partes del caso." (Tradução nossa). 
A partir do Caso Apitz Barbera y Otros Vs Venezuela (CORTEIDH, 2008), a CorteIDH retoma estes preceitos $(\mathbb{S} 56)^{12}$ e novamente utilizando-se de precedentes do TEDH (Notas de rodapé 71 e 72), passa a melhor desenvolvê-los (SALMÓN; BLANCO, 2012, p. 138). Importante ressaltar que, muito embora sejam ambos os aspectos igualmente ensejadores de violação ao artigo 8.1 da Convenção Americana, e nem sempre sua diferenciação fique muito nítida nos casos analisados pela CorteIDH, há delineamentos importantes que podem ser extraídos que dizem respeito a cada um deles que se tornam significativos para a análise que aqui se pretende.

No que diz respeito ao aspecto subjetivo, este foi preliminarmente invocado pela CorteIDH em casos envolvendo julgamento de militares por tribunais castrenses, que seriam por si só imparciais (CORTEIDH, 1999, Caso Castillo Petruqzi y otros Vs Perú, SS 127-131; CORTEIDH, 2005, Caso Palamare Iribarne $V s$ Chile, \155), diante da falta de independência necessária para o exercício da jurisdição (CORTEIDH, 2005, Caso Palamare Iribarne Vs Chile, \157; LANDA ARROYO, 2012, p. 123).

Em outros casos, a CorteIDH estabeleceu que a imparcialidade pelo aspecto subjetivo implica no dever de os integrantes de um tribunal não terem interesse direto, uma posição tomada, uma preferência por alguma das partes e de não se encontrarem envolvidos na controvérsia (CORTEIDH, 2005, Caso Palamare Iribarne Vs Chile, \146 ${ }^{13}$; Caso Acosta y Otros Vs Nicaragua, 2017, \$172). Ou seja, ela exige uma postura subjetiva de equidistância entre as partes, de forma que as convicções pessoais do julgador não interfiram na apreciação do direito. Associa-se, em essência, às hipóteses de suspeição e impedimento das autoridades judiciais no direito brasileiro (CUNHA, BASTOS JR, 2021, p. 158).

12 "De outro lado, a imparcialidade exige que a autoridade judicial que intervenha em determinada controvérsia analise os fatos da causa afastando-se, de maneira subjetiva, de qualquer preconceito e, ainda, ofereça garantias suficientes de natureza objetiva que permitam afastar qualquer dúvida de que o réu ou a comunidade podem alegar quanto à ausência de imparcialidade." "En cambio, la imparcialidad exige que el juez que interviene en una contienda particular se aproxime a los hechos de la causa careciendo, de manera subjetiva, de todo prejuicio y, asimismo, ofreciendo garantias suficientes de indole objetiva que permitan desterrar toda duda que el justiciable o la comunidad puedan albergar respecto de la ausencia de imparcialidade." (Tradução nossa).

13 "La imparcialidad del tribunal implica que sus integrantes no tengan un interés directo, una posición tomada, una preferencia por alguna de las partes y que no se encuentren involucrados en la controversia." (Tradução nossa). 
Ainda que isso não pareça ter direta relação com a temática de fundo desse estudo, há alguns contornos realizados pela CorteIDH que merecem destaque. Segundo esta, a imparcialidade subjetiva se presume, ou seja, em geral, os juízes e tribunais são imparciais subjetivamente, razão por que o reconhecimento de sua violação exige prova concreta que desconstitua essa presunção legal (CORTEIDH, 2008, Caso Apitz Barbera y Otros Vs Venezuela, $\left.\int 56^{14}\right)$. Para tanto, deve-se demonstrar que os magistrados estão atuando segundo interesses pessoais (CORTEIDH, 2012, Caso Atala Riffo y Niñas Vs Chile, \234).

Apesar de reconhecer a existência desta presunção (em favor da imparcialidade subjetiva), a própria CorteIDH reconheceu que esta deve ceder quando se demonstrar que dispositivos legais do direito interno, ou ainda, a jurisprudência consolidada dos tribunais, impeça às partes que provoquem a arguição de suspeição em situações concretas em consideração (CORTEIDH, 2008, Caso Apitz Barbera y otros vs Venezuela, \66).

Isso porque, de acordo com o entendimento consolidado da CorteIDH, em decorrência do próprio art. $2^{\circ} \mathrm{da} \mathrm{CADH}^{15}$, tais garantias devem ser "efetivas" (princípio do effet utile $e^{16}$ ) (FERRAR MAC-GREGOR, 2013, p. 667), ou seja, a fim de que se confira credibilidade ao exercício da jurisdição doméstica, deve existir a possibilidade concreta de se arguir a "recusa" da autoridade judicial. Esse instituto permite a elas pedir o afastamento desta autoridade quando existam elementos convincentes, temores fundados ou

14 “[...] A Corte Europeia de Direitos Humanos explicou que a imparcialidade pessoal ou subjetiva se presume, a menos que exista prova em contrário [...]". "[...] La Corte Europea de Derechos Humanos ha explicado que la imparcialidad personal o subjetiva se presume a menos que exista prueba en contrario [...]”. (Tradução nossa).

15 Artigo 2. Dever de adotar disposições de direito interno. Se o exercício dos direitos e liberdades mencionados no artigo 1 ainda não estiver garantido por disposições legislativas ou de outra natureza, os Estados Partes comprometem-se a adotar, de acordo com as suas normas constitucionais e com as disposições desta Convenção, as medidas legislativas ou de outra natureza que forem necessárias para tornar efetivos tais direitos e liberdades.

${ }^{16}$ Aqui a observância da "efetividade" cobra relevância nos termos do princípio do efeito útil, que significa que o Estado deve adotar todas as medidas necessárias para que o estabelecido na Convenção seja realmente cumprido, motivo pelo qual a CorteIDH considera necessário reafirmar que tal obrigação, por sua própria natureza, constitui uma obrigação de resultado. "Aqui la observancia de la "efectividad" cobra relevancia en términos del principio del effet utile "lo que significa que el Estado debe adoptar todas las medidas necesarias para que lo establecido en la Convención sea realmente cumplido"; por lo que la Corte IDH ha considerado necesario reafirmar que dicha obligación, por su propia naturaleza, constituye una obligación de resultado." (Tradução nossa). 
suspeitas legítimas de parcialidade sobre sua pessoa, fazendo concluir que sua decisão seja vista como motivada por razões externas ao Direito e que, por isso, o funcionamento do sistema judicial venha a ser distorcido (CORTEIDH, 2008, Caso Apitz Barbera y otros vs Venezuela, $\int 63^{17}$ ).

Neste aspecto, ainda que haja a previsão legal do instituto no código processual civil, aplicado subsidiariamente ao contencioso eleitoral, há uma decisão e uma prática que não só permite, como integra, uma autoridade na revisão de sua própria decisão. Isso fica demonstrado não só devido à Súmula n 72 do STF e com relação aos ministros e ministras comuns entre a Corte Eleitoral e a Corte Constitucional, como também quando o TSE nega vigência, em outras ocasiões, a tais dispositivos ${ }^{18}$.

Diante disso, mesmo que as partes não estejam impedidas de arguir, na prática tais regras não se mostram efetivas para resguardar a devida imparcialidade subjetiva.

17 "Al respecto, el Tribunal considera que la institución de la recusación tiene un doble fin: por un lado actúa como una garantía para las partes en el proceso, y por el otro, busca otorgar credibilidad a la función que desarrolla la Jurisdicción. En efecto, la recusación otorga el derecho a las partes de instar a la separación de un juez. cuando, más allá de la conducta personal del juez cuestionado, existen hechos demostrables o elementos convincentes que produrcan temores fundados o sospechas legitimas de parcialidad sobre su persona, impidiéndose de este modo que su decisión sea vista como motivada por razones ajenas al Derecho y que, por ende, el funcionamiento del sistema judicial se vea distorsionado. La recusación no debe ser vista necesariamente como un enjuiciamiento de la rectitud moral del funcionario recusado, sino más bien como una herramienta que brinda confianza a quienes acuden al Estado solicitando la intervención de órganos que deben ser y aparentar ser imparciales." (Tradução nossa).

${ }^{18}$ Nesse sentido decidiu o TSE: "EXCEÇÃO DE IMPEDIMENTO. PRESIDENTE DO TRIBUNAL. DECISÃO DE ADMISSIBILIDADE DO RECURSO EXTRAORDINÁRIO INTERPOSTO CONTRA ACÓRDÃO QUE FORA POR ELE RELATADO. IMPEDIMENTO NÃO CARACTERIZADO. 1. Presidente deste Tribunal Superior Eleitoral que nega seguimento a recurso extraordinário interposto contra acórdão do qual fora anteriormente relator. 2. Inexistência de lei que preveja impedimento nesse caso, que não configura a hipótese prevista no art. 134, III, do CPC. Precedentes. 3. Exceção rejeitada. (Exceção no 47122, Acórdão, Relator(a) Min. Maria Thereza de Assis Moura, Publicação: DJE - Diário de justiça eletrônico, Tomo 201, Data 22/10/2015, Página 29/30). Esta decisão foi proferida na vigência do CPC/73, cujo art. 134 III corresponde ao atual art. 144 II do CPC/15 que tem a seguinte redação: "Art. 144. Há impedimento do juiz, sendo-lhe vedado exercer suas funções no processo: [...] II - de que conheceu em outro grau de jurisdição, tendo proferido decisão;" Ou seja, não deveria ser feito um juízo de admissibilidade ante a interposição de Recurso Especial Eleitoral considerando que a autoridade que vai apreciar sua admissibilidade (podendo negar-lhe seguimento) integrou o julgamento da Corte que se pretende ver reformado pela instância superior. 
Já com relação à imparcialidade no aspecto objetivo, a CorteIDH utilizou-se novamente de precedentes do TEDH, e também dos Princípios Básicos das Nações Unidas Relativos à Independência do Judiciário (CORTEIDH, 2008, Caso Apitz Barbera y otros Vs Venezuela, nota de rodapé nos 73 e 74), para dizer que esta consiste em "determinar se a autoridade judicial em questão ofereceu elementos convincentes que permitam eliminar temores legítimos ou fundadas suspeitas de parcialidade sobre sua pessoa, o que implica no dever de demonstrar que atua sem estar sujeito à influência, incentivo, pressão ameaça ou intromissão, direta ou indireta, mas sim única e exclusivamente segundo a - e movido pela - lei"19 (CORTEIDH, 2008, Caso Apitz Barbera y otros vs Venezuela, \56).

$\mathrm{Na}$ análise da vertente objetiva da imparcialidade, ainda, não se questiona as capacidades pessoais ou as convicções dos julgadores sobre o caso concreto ou suas possíveis relações com as partes, mas sim os fatos que razoavelmente poderiam justificar falta de confiança naqueles (CORTEIDH, 2018, Caso V.R.P., V.P.C. y otros Vs Nicaragua, \ 24120). Dessa forma, utilizando-se da "Teoria das Aparências" do TEDH, a CorteIDH sustenta que até mesmo a aparência tem importância pois o que está em jogo é a confiança que os tribunais devem inspirar aos cidadãos em uma sociedade democrática e, sobretudo, às partes do caso (CORTEIDH, 2018, Caso V.R.P., V.P.C. y otros Vs Nicaragua, nota de rodapé 324 e $\int 242^{21}$; SALMÓN; BLANCO, 2012, p. 140).

19 “[...] Por su parte, la denominada prueba objetiva consiste en determinar si el juez. cuestionado brindó elementos convincentes que permitan eliminar temores legítimos o fundadas sospechas de parcialidad sobre su persona. Ello puesto que el juez debe aparecer como actuando sin estar sujeto a influencia, aliciente, presión, amenaza o intromisión, directa o indirecta, sino única y exclusivamente conforme a -y movido porel Derecho." (Tradução nossa).

20 "Com efeito, a Corte destaca que, na análise da vertente objetiva da imparcialidade, não se questiona as capacidades pessoais ou as convicções sobre o caso concreto dos julgadores ou suas possíveis relações com as partes, mas sim fatos que razoavelmente poderiam justificar falta de confiança por um observador objetivo em quem se encontra a cargo da importante missão de fazer justiça em um determinado caso." "En efecto, la Corte resalta que en el análisis de la vertiente objetiva de la imparcialidad no se cuestiona las capacidades personales o las convicciones sobre el caso concreto de los juzgadores o sus posibles relaciones con las partes, sino hechos que razonablemente podrian justificar en un observador objetivo falta de confianza en quienes se encuentran a cargo de la importante misión de impartir justicia en un determinado caso." (Tradução nossa).

21 "Sob esta órbita, o Tribunal Europeu especificou que: pelo aspecto objetivo, deve ser determinado se, além do comportamento pessoal dos juízes, existem fatos averiguáveis que podem suscitar dúvidas relativas a sua imparcialidade. Nesse sentido, até as aparências 
A CorteIDH considerou que houve violação ao dever de imparcialidade, na vertente objetiva, em casos em que essa confiança foi colocada em xeque, em razão de elementos que ultrapassaram a seara afeta às autoridades judiciais e ao exercício da adjudicação e eram perceptíveis por qualquer pessoa que as observassem (CORTEIDH, Caso V.R.P., V.P.C. y otros Vs Nicaragua \241).

De destaque para o estudo que aqui se desenvolve, estão o já citado Caso Herrera Ulloa Vs Costa Rica e o Caso Usón Ramirez vs Venezuela, em que a CorteIDH concluiu pela falta de parcialidade de autoridades porque estas participaram de diferentes momentos decisivos de processos, motivo pelo qual serão abordados de forma mais aprofundada.

O Caso Herrera Ulloa Vs Costa Rica trata de um processo penal eivado de irregularidades, levado a cabo pelo Estado da Costa Rica, que culminou numa sentença condenatória proferida pelo Tribunal Penal del Primer Circuito Judicial de San Jose contra o então jornalista Mauricio Herrera Ulloa pelo suposto cometimento de quatro delitos de difamação, devido a uma série de artigos publicados por ele no jornal La Nación. Tais publicações consistiam numa reprodução parcial de reportagens da imprensa belga que atribuíam ao diplomata Félix Przedborski, representante honorário da Costa Rica na Organização Internacional de Energia Atômica na Áustria, o cometimento de ilícitos graves (CORTEIDH, 2004, Caso Herrera Ulloa Vs Costa

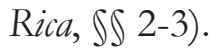

Dentre as violações de direitos humanos apontadas, está a acusação de que não foi garantido ao Sr. Herrero Ulloa o direito a um julgamento imparcial. O Sr. Félix Przedborski ingressou com duas queixas crime nos tribunais costarriquenses contra o jornalista pelos delitos de difamação, calúnia e demais ofensas, bem como ajuizou uma ação civil indenizatória (CORTEIDH, 2004, Caso Herrera Ulloa Vs Costa Rica, \ 95.p). Em 29 de maio de 1998, o Tribunal Penal del Primer Circuito Judicial de San Jose emitiu uma sentença absolvendo o Sr. Herrero Ulloa das acusações, por entender que

poderão ter certa importância. O que está em jogo é a confiança que devem inspirar os tribunais aos cidadãos em uma sociedade democrática e, principalmente, às partes do caso.” "Bajo esta órbita, el Tribunal Europeo ha especificado que: [b]ajo el análisis objetivo, se debe determinar si, aparte del comportamiento personal de los jueces, hay hechos averiguables que podrán suscitar dudas respecto de su imparcialidad. En este sentido, hasta las apariencias podrán tener cierta importancia. Lo que está en juego es la confianza que deben inspirar los tribunales a los ciudadanos en una sociedad democrática, y sobre todo, en las partes del caso." (Tradução nossa). 
este não teria tido dolo nas condutas, bem como declarou improcedente a ação civil (CORTEIDH, 2004, Caso Herrera Ulloa Vs Costa Rica, \95.q).

O advogado do Sr. Przedborski interpôs um recurso perante a Sala Tercera de la Corte Suprema de Justicia de Costa Rica, a qual anulou a sentença absolutória, alegando que a fundamentação não teria sido suficiente para descartar o dolo existente nas condutas praticadas e determinou o reenvio para ao tribunal originário para que se proferisse nova manifestação (CORTEIDH, 2004, Caso Herrera Ulloa Vs Costa Rica, \$S 95.r-95.s).

Em 12 de novembro de 1999, o Tribunal Penal del Primer Circuito Judicial de San Jose emitiu nova sentença, dessa vez condenando o Sr. Herrero Ulloa ao pagamento de multa, indenização por danos morais e impondo o dever de publicar a sentença no mesmo veículo de imprensa em que as reportagens foram veiculadas (jornal La Nación) e de retirá-las dos meios digitais (CORTEIDH, 2004, Caso Herrera Ulloa Vs Costa Rica, \$S 95.t-95.u).

Por sua vez, o advogado de defesa interpôs novo recurso contra esta nova sentença, o qual foi novamente submetido à Sala Tercera de la Corte Suprema de Justicia, que lhe negou provimento, fazendo transitar em julgado, portanto, a sentença condenatória (CORTEIDH, 2004, Caso Herrera Ulloa

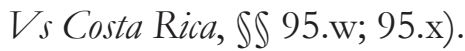

Ocorre que esta turma de julgadores, que julgou ambos os recursos, primeiramente o da acusação e depois o da defesa, foi composta pelas mesmas autoridades, sendo estes quatro magistrados titulares e um suplente (CORTEIDH, 2004, Caso Herrera Ulloa Vs Costa Rica, \95. $\mathrm{y}^{22}$ ).

Ao se debruçar sobre a questão, a CorteIDH entendeu que as autoridades que haviam julgado o recurso contra a sentença absolutória deveriam ter se declarado impedidas para conhecer do recurso contra a nova sentença, dessa vez condenatória, tendo em vista que, quando julgaram o primeiro, elas se debruçaram não só sobre questões processuais, mas tam-

22 "A Terceira Sala de Justiça da Costa Rica que deixou sem efeitos os recursos de cassação (supra par. 95.x) era composta pelos mesmos magistrados que decidiram o recurso de cassação interposto pelo advogado do Sr. Félix Przedborski, mediante decisão de 7 de maio de 1999 (supra par. 95.2) e ordenaram a anulação da sentença absolutória de 29 de maio de 1998 (supra par. 95.q)." "La Sala Tercera de la Corte Suprema de Justicia de Costa Rica que declaró sin lugar los dos recursos de casación (supra párr. 95. x) estaba integrada por los mismos magistrados que resolvieron el recurso de casación interpuesto por el abogado del señor Félix Przedborski mediante decisión de 7 de mayo de 1999 (supra párr. 95. s) y ordenaron la anulación de la sentencia absolutoria de 29 de mayo de 1998 (supra párr. 95. q)." (Tradução nossa). 
bém analisaram o mérito da questão (CORTEIDH, 2004, Caso Herrera Ulloa Vs Costa Rica, $\left.\int 174^{23}\right)$. Por isso, ao julgarem e decidirem sobre o segundo recurso, não teriam cumprido com a exigência de imparcialidade que lhes era exigida, pois essa postura não garantiu a objetividade para o julgamento que conferiria a confiança necessária às partes do caso, assim como aos demais cidadãos (CORTEIDH, 2004, Caso Herrera Ulloa Vs Costa Rica, (\175 e $\left.\int 171\right)$.

O Caso Usón Ramirez vs Venezuela trata também de um processo penal, instaurado contra um general aposentado da Fuerza Armada Nacional venezuelana, Sr. Francisco Usón Ramirez. Usón Ramirez era general de brigada, tendo ocupado diversos cargos públicos, inclusive Ministro de Finanças, mas renunciou ao cargo e se aposentou após se desentender com o governo e com membros do alto comando militar (CORTEIDH, Caso Usón Ramirez,vs Venequela, 2009c, \36).

Já durante sua aposentadoria, Usón Ramirez participou de um programa de televisão, em que se discutiu uma reportagem que denunciou o uso de um "lança-chamas" como meio de castigo contra um soldado na instalação militar Fuerte Mara, que acabou ocasionando um incêndio. Ao se pronunciar sobre o assunto, o Sr. Usón Ramirez alegou que para se utilizar tal equipamento, era necessário seguir uma série de procedimentos que não teriam sido observados, o que poderia indicar que houve uma premeditação do ocorrido e que se isso se confirmasse, seria muito grave (CORTEIDH, Caso Usón Ramirez vs Venezuela, 2009c, \37).

Como consequência destas declarações, o Sr. Usón Ramirez foi julgado e condenado a cumprir uma pena de cinco anos e seis meses de prisão pelo delito de injúria contra a Fuerza Armada Nacional (CORTEIDH, Caso Usón Ramirez vs Venezuela, 2009c, \38).

No que diz respeito às garantias judiciais do art. $8^{\circ}$ da $\mathrm{CADH}$, além de a CorteIDH se debruçar sobre a (in)competência do tribunal mili-

23 "Os magistrados da Terceira Sala da Corte Suprema de Justiça deveriam se abster de conhecer os recursos de cassação interpostos contra a sentença condenatória de 12 de novembro de 1999 porque, considera esta Corte, que ao decidir o recurso de cassação contra sentença absolutória de 29 de maio de 1998, os mesmos magistrados haviam analisado parte do mérito e não somente se pronunciaram sobre a forma." "Los magistrados de la Sala Tercera de la Corte Suprema de Justicia debieron abstenerse de conocer los dos recursos de casación interpuestos contra la sentencia condenatoria de 12 de noviembre de 1999 porque, considera esta Corte, que al resolver el recurso de casación contra la sentencia absolutoria de 29 de mayo de 1998, los mismos magistrados habian analizado parte del fondo, y no solo se pronunciaron sobre la forma." (Tradução nossa). 
tar para julgar civis, tendo em vista que o Sr. Usón Ramirez já se encontrava aposentado, analisou o transcorrer do processo também pela perspectiva da imparcialidade para julgamento.

Reafirmando seus padrões interpretativos acerca da imparcialidade, dando ênfase à vertente objetiva (CORTEIDH, Caso Usón Ramirez vs Venezuela, 2009c, \117), a CorteIDH foi enfática ao determinar que:

Uma autoridade julgadora deve se afastar de um caso submetido a seu conhecimento quando houver qualquer motivo ou dúvida que prejudique a integridade do tribunal como um órgão imparcial. Para salvaguardar a administração da justiça, deve ser assegurado que a autoridade judicial esteja livre de todo preconceito e que não haja receio que coloque em xeque o exercício das funções jurisdicionais ${ }^{24}$ (CORTEIDH, Caso Usón Ramirez vs Venezuela, 2009c, \118).

Essa aparência de imparcialidade se viu afetada porque um dos magistrados que compunha a Sala de Casación Penal del Tribunal Supremo de Justicia, que conheceu e julgou um recurso interposto pelo Sr. Usón Ramírez, era a mesma autoridade que, como Fiscal General Militar, ordenou primeiramente que se iniciasse a investigação contra ele. Reforçando o já delimitado no caso Herrero Ulloa, a CorteIDH entendeu que ele deveria ter se declarado impedido e se abstido do julgamento posterior, não garantindo, portanto, a devida imparcialidade prevista no art. 8.1 da CADH (CORTEIDH, Caso Usón Ramirez vs Venequela, 2009c, \119²5).

24 "Consecuentemente, esta Corte ha señalado anteriormente que un juez debe separarse de una causa sometida a su conocimiento cuando exista algún motivo o duda que vaya en desmedro de la integridad del tribunal como un órgano imparcial. En aras de salvaguardar la administración de justicia se debe asegurar que el juez se encuentre libre de todo prejuicio y que no exista temor alguno que ponga en duda el ejercicio de las funciones jurisdiccionales." (Tradução nossa).

25 "No presente caso, restou comprovado que o senhor Eladio Ramón Aponte Aponte, um dos magistrados da Sala de Cassação Penal do Tribunal Supremo de Justiça que conheceu o recurso de cassação interposto pelo senhor Usón Ramirez, havia sido quem, como Fiscal General Militar, ordenou iniciar a investigação contra ele. Apesar disso, tal fiscal/ magistrado não deixou de conhecer da causa nem aceitou o pedido para seu impedimento. Ao ter participado em uma primeira etapa, ordenando a abertura da investigação contra o senhor Usón Ramirez, tal fiscal/magistrado não deveria ter intervido em um posterior julgamento. Tais fatos não foram justificados pelo Estado de maneira convincente (supra par. 106). Por isso, o Tribunal considera que o Estado violou o direito do senhor Usón Ramirez a ser julgado por um tribunal imparcial, o que constitui uma violação ao artigo 8.1 da Convenção, combinado com o artigo 1.1 do mesmo instrumento." "En el presente caso, 
Importante destacar que neste caso, diferentemente do anterior, a CorteIDH não fez uma análise sobre o alcance da atuação da autoridade, no que diz respeito a questões de mérito, para considerá-la imparcial, muito embora isso pudesse ser deduzido do fato de que, para se instaurar um procedimento penal investigatório, teoricamente há que se debruçar minimamente sobre indícios de autoria e materialidade. Entretanto, no caso não restou claro que tipo de investigação foi iniciada, somente que se tratou de uma investigação penal levado a cabo pela instância ordinária militar, cujo início foi ordenado pela autoridade em questão, que atuou posteriormente em grau recursal, o que por si só levou a CorteIDH concluir por sua imparcialidade.

Não obstante, a partir destes últimos precedentes, a CorteIDH fixa um importante padrão interpretativo no que diz respeito à limitação de atuação das autoridades judiciais: o de que a participação em diferentes momentos decisivos do processo (inclusive na fase preliminar investigatória) e em diferentes graus recursais fere a imparcialidade objetiva.

Esses são parâmetros que sem dúvida colocam em xeque a ampla competência conferida à autoridade eleitoral brasileira, não só pelo compartilhamento de autoridades judiciais de outras esferas nos tribunais sem a observância do dever de suspeição e/ou impedimento, com destaque especial ao trânsito entre STF e TSE, como também pela possibilidade destas de conduzirem processos no grau ordinário originados a partir de suas atuações administrativas.

O direito de julgar (e punir) destas autoridades está inserido na prerrogativa exclusiva do Estado de garantir a integridade jurídica (no caso, a "normalidade e legitimidade das eleições", nos termos do \ 9 do art. 14 da Constituição Federal). Entretanto, no afã de garantir esta "ordem”, dá-se sobremaneira valor axiológico ao princípio da celeridade, perante o qual

ha quedado demostrado que el señor Eladio Ramón Aponte Aponte, uno de los magistrados de la Sala de Casación Penal del Tribunal Supremo de Justicia que conoció el recurso de casación interpuesto por el señor Usón Ramírez, habia sido quien, como Fiscal General Militar, ordenó iniciar la investigación en contra de éste. Sin embargo, dicho fiscal/ magistrado no se inbibió de conocer la causa ni aceptó la recusación en su contra. Al haber participado en una primera etapa ordenando la apertura de la investigación en contra del señor Usón Ramírez, dicho fiscal/ magistrado no debió haber intervenido en el posterior juzgamiento. Tales hechos no fueron desvirtuados por parte del Estado de manera convincente (supra párr. 106). Por lo tanto, el Tribunal considera que el Estado violó el derecho del señor Usón Ramírez a ser juzgado por un tribunal imparcial, lo que constituye una violación del artículo 8.1 de la Convención, en relación con el artículo 1.1 del mismo instrumento." (Tradução nossa). 
muitas vezes os direitos políticos deixam de ser percebidos como fundamentais (GRESTA, 2019, p. 137), passando-se por cima das garantias do devido processo e, notadamente, da imparcialidade para julgamento.

A garantia da imparcialidade, sobrepondo-se à perspectiva positivista e de obrigação de neutralidade com as partes, traduz-se também num dever que obriga estes atores não só com a Constituição e a lei, mas com os tratados internacionais, e não só no sentido formal, mas também no material, isto é, em defesa dos direitos humanos (LANDA ARROYO, 2012, p. 123). O direito a um julgamento imparcial, em todos os seus aspectos, conforme visto, é uma regra fundamental do devido processo, constitucional e convencional, que busca garantir que quem exerça a função de levar a cabo um julgamento tenha a maior objetividade para enfrentá-lo.

Diante do que aqui foi exposto, pode-se extrair os seguintes $p a-$ drões interpretativos ${ }^{26}$ (res interpretata) (FERRER MAC-GREGOR, 2013, p. 641-694) advindos da Corte Interamericana acerca da imparcialidade para julgamento:

a) O dever de imparcialidade é uma garantia do devido processo convencional, extraído a partir do art. 8.1 da Convenção Americana, essencial para a garantia de obtenção de decisões justas (Caso Herrera Ulloa, \$171; Caso Usón Ramirez, \117; Caso Palamare Iribarne, \145);

b) Em sua vertente subjetiva, esta garantia proíbe que as autoridades judiciais que intervenham num processo julguem baseadas em preconceitos e convicções pessoais, bem como tenham interesse direto, uma posição tomada, preferência por alguma das partes ou estejam envolvidos na controvérsia (Caso Palamare Iribarne, \146; Caso Apitz, Barbera y otros, $\int 56$; Caso Acosta y Otros, \ 172; Caso V.R.P., V.P.C. y otros, \239; Caso Atala Riffo y Niñas, \234; Caso Usón Ramirez, \117);

c) O dever de imparcialidade implica também em o Poder Judiciário transparecer objetivamente que atua sem estar sujeito a influência, pressão, ameaça ou intromissão, atuando única e exclusivamente conforme o Direito, inspirando a confiança necessária aos cidadãos em uma sociedade

${ }^{26}$ A literatura especializada, por ser maioria espanhola, costuma se referir às diretrizes emanadas da Corte Interamericana de Direitos Humanos na sua atividade interpretativa como "estándar", inclusive a própria. No Brasil, sem que se saiba o porquê, o termo costumeiramente usado é o inglês "standard", ou formas adaptadas como "standart". Neste trabalho, optou-se por utilizar a tradução literal para o termo em português "padrão" para nos referirmos aos estándares emanados deste tribunal internacional. 
democrática (Caso Palamare Iribarne, \ 145; Caso Apitz Barbera y otros, \56; Caso Acosta y Otros, \ 172; Caso V.R.P., V.P.C. y otros, \239-241; Caso Herrera Ulloa, \171; Caso Usón Ramirez, \117); e, especialmente

d) A vertente objetiva da imparcialidade implica ainda no dever de as autoridades judiciais se declararem impedidas de atuarem num mesmo caso, em diferentes momentos processuais (Caso Herrera Ulloa, \ 174-175; Caso Usón Ramirez, \118-119).

Diante disso, pode-se concluir que a ampla competência jurisdicional da autoridade eleitoral brasileira é inconvencional, pois permite que esta acumule funções administrativas e contenciosas que se sobrepõem, atue na mesma lide em diferentes momentos processuais e instâncias recursais, colocando em xeque seu dever de imparcialidade, especialmente na vertente objetiva.

\section{Conclusão}

Um dos elementos fundamentais do devido processo legal, e do Estado democrático brasileiro, é a imparcialidade das autoridades judiciais. Enquanto investido da função estatal, a autoridade judicial deve apego à lei, à Constituição e aos tratados internacionais de proteção, em respeito, em essência, à soberania popular, tendo em vista que suas decisões se dão de maneira contramajoritária.

O limbo, proposital ou não, em que se desenvolveu a Justiça Eleitoral permitiu que se perpetuasse uma estrutura judicial ímpar no direito brasileiro que vai de encontro a esta premissa. Embora isso possa ter parecido interessante como resposta aos problemas do sistema político de controle das eleições, sua estrutura e funcionamento não se coadunam com as exigências democráticas dos Estados contemporâneos. Faz-se necessário repensar a opção e suas engrenagens. É urgente a alteração, pela perspectiva dos direitos políticos fundamentais, da forma de investidura e a atribuição de competência da autoridade eleitoral que, conforme visto, vai de encontro aos critérios convencionais para garantia de imparcialidade de julgamento.

Essa falta de parcialidade torna-se sobremaneira grave quando se pensa pela perspectiva do comando constitucional de legitimidade e normalidade das eleições. Se a atuação judicial é um dos fatores determinantes para que se garanta uma eleição sem vícios, abusos e fraudes, a fim de que a escolha do eleitorado seja livre e autêntica, quando ela própria não está or- 
ganizada para interferir na competição de forma justa e equânime, o que se permite é que se torne, do contrário, vetor de desestabilização democrática e de desrespeito à soberania popular (SALGADO, 2016, p. 187).

Entretanto, analisar estes outros fatores, bem como a melhor forma com que a Justiça Eleitoral deva se reestruturar, a fim de readequá-la, seja com a separação das funções administrativas e jurisdicionais, seja com a criação de uma carreira própria para as autoridades eleitorais, dentre outras, conforme preliminarmente delimitado, foge ao escopo desse trabalho e será explorado oportunamente.

Não obstante, até que isso seja enfrentado e debatido, pela adequada via legislativa, a fim de cumprir com as exigências convencionais, e constitucionais, do devido processo, pode-se elencar desde já as seguintes premissas: i) as autoridades eleitorais devem atuar com exclusividade e as funções administrativas e contenciosas não podem ser cumulativas; ii) as autoridades eleitorais não podem julgar demandas contenciosas interpostas com fundamento nas próprias decisões administrativas; iii) não pode haver juízo de admissibilidade por presidente ou presidenta dos tribunais que participou do julgamento recorrido; iv) há a necessidade de fixação obrigatória de impedimento às autoridades judiciais que atuaram anteriormente no feito, independente do grau recursal; e, em especial, v) os Ministros ou Ministras do STF, que integrem o TSE, devem estar impedidos de participar de deliberações que visem a revisão de decisões da Corte Eleitoral.

Sendo assim, cabe à autoridade eleitoral brasileira, diante das obrigações internacionais assumidas pelo Estado brasileiro e ao seu dever de realizar o controle de convencionalidade de ofício, atuar em observância aos limites impostos no que diz respeito à garantia convencional de imparcialidade para tomada de suas decisões.

\section{Referências}

ÁLVAREZ GONZÁLEZ, Juan Manuel. Algunos principios del derecho penal sustantivo aplicables al derecho sancionador electoral. In: CIENFUEGOS SALGADO, David; CIFUENTES VARGAS, Manuel. E1 ilícito y su castigo: reflexiones sobre la cadena perpetua, la pena de muerte y la idea de sanción en el derecho. México: Laguna; Fundación Académica Guerrerense; Universidad Autónoma de Guerrero, Maestría en Derecho Público, Universidad Autónomade Sinaloa, Unidad de Posgrado en Derecho, 2009. p. 17-46. 
BASTOS JÚNIOR, Luiz Magno Pinto; CAMPOS, Thiago Yukio Guenka. Para além do debate em torno da hierarquia dos tratados: do duplo controle vertical das normas internas em razão dos tratados de direitos humanos. Revista da Faculdade de Direito da UERJ, v. 1, n. 19, jun.-dez. 2011. BOBBIO, Norberto. O futuro da democracia. Tradução de Marco Aurélio Nogueira. São Paulo: Paz e Terra, 2000.

CUNHA, Amanda Guimarães da; BASTOS JR, Luiz Magno Pinto. Direito eleitoral sancionador: o dever de imparcialidade da autoridade judicial. 1 ed. São Paulo: Tirant Lo Blanch, 2021, 186p.

FERRER MAC-GREGOR, Eduardo. Interpretacíon conforme y control difuso de convencionalidad. El nuevo paradigma para el juez mexicano. Revista Estudios Constitucionales, Año 9, n. 2, p. 531-622, 2011. Disponível em: https://scielo.conicyt.cl/pdf/estconst/v9n2/art14.pdf

FERRER MAC-GREGOR, Eduardo. Eficacia de la sentencia interamericana y la cosa juzgada internacional: vinculación directa hacia las partes (res judicata) e indirecta hacia los Estados Parte de la Convención Americana (res interpretata) (sobre el cumplimiento del Caso Gelman vs. Uruguay). Estudios Constitucionales, ano 11, n. 2, p. 641-694, 2013.

GRESTA, Roberta Maia. Teoria do Processo Eleitoral Democrático: a formação dos mandatos a partir da perspectiva da cidadania. 2019. 499fls. Tese (Doutorado) - Universidade Federal de Minas Gerais, Belo Horizonte, MG, 2019.

GUERRERO PALOMARES, Salvador. La imparcialidad objetiva del juez penal: análisis jurisprudencial y valoración crítica. Navarra: Thomson Reuters, 2009.

LANDA ARROYO, César. El Derecho al Debido Proceso em La Jurisprudencia: Corte Suprema de Justicia de la República del Perú, Tribunal Constitucional del Perú, Corte Interamericana de Derechos Humanos. Colección Cuadernos de Análisis de la Jurisprudencia. v. 1. Lima, Perú, diciembre del 2012. Disponível em: http://repositorio.amag.edu.pe/handle $/ 123456789 / 37$

PEREIRA, Kate Cibele. O poder de polícia no juízo eleitoral: a constitucionalidade no julgamento de processos ocasionados da apuração administrativa de ilícitos feita pelo judiciário. Revista Brasileira de Direito, Passo Fundo, v. 11, n. 1, p. 90-99, ago. 2015. ISSN 2238-0604. Disponível em: https://seer. imed.edu.br/index.php/revistadedireito/article/view/715/963. 
SALGADO, Eneida Desiree. Administración de las elecciones y jurisdicción electoral: un análisis del modelo mexicano y una crítica a la opción brasilera. México: Universidad Nacional Autónoma de México, Instituto de Investigaciones Juridicas, 2016, 248p.

SALMÓN, Elizabeth; BLANCO, Cristina. El derecho al debido proceso en la jurisprudencia de la Corte Interamericana de Derechos Humanos. Instituto de Democracia y Derechos Humanos de la Pontificia Universidad Católica del Perú (IDEHPUCP), Primera edición: febrero de 2012. Disponível em: http://idehpucp.pucp.edu.pe/images/publicaciones/derecho_ al_debido_proceso_en_jurisprudencia_de_corte_interamericana_ddhh.pdf ZILIO, Rodrigo López. Decisão de cassação de mandato: um método de estruturação (os critérios de conformação democrática). Salvador: JusPodivm, 2020.

ZULINI, Jaqueline Porto. Por além do discurso moralizador: os interesses políticos e o impacto da criação da justiça eleitoral em 1932. In: RICCI, Paolo (org.). O autoritarismo eleitoral dos anos trinta e o código eleitoral de 1932. Curitiba: Appris, 2019. p. 418-515.

\section{Fontes documentais}

BRASIL. Supremo Tribunal Federal. Súmula n⿳ำ 72, julgada na Sessão Plenária de 13/12/1963. Disponível em: http:/ /www.stf.jus.br/portal/jurisprudencia/ listarJurisprudencia.asp?s1 =72.NUME. $\% 20$ NAO $\% 20$ S.FLSV.\&base=baseSumulas

BRASIL. Decreto no 21.076, de 24 de fevereiro de 1932. Código Eleitoral (1932). Disponível em: https://www2.camara.leg.br/legin/fed/ decret/1930-1939/decreto-21076-24-fevereiro-1932-507583-norma-pe.html

BRASIL. Lei no 4.737, de 15 de julho de 1965. Institui o Código Eleitoral. Disponível em: http://www.planalto.gov.br/ccivil_03/leis/14737compilado. htm

BRASIL. Lei Complementar nº 64, de 18 de maio de 1990. Estabelece, de acordo com o art. 14, $\int 9^{\circ}$ da Constituição Federal, casos de inelegibilidade, prazos de cessação, e determina outras providências. Disponível em: http:// www.planalto.gov.br/ccivil_03/leis/lcp/lcp64.htm 
BRASIL. Tribunal Superior Eleitoral. Resolução nº 20.951 de 13 de dezembro de 2001. Dispõe sobre as reclamações e representações de que cuida o art. 96 da Lei $\mathrm{n}^{\circ} 9.504 / 97$ e sobre os pedidos de direito de resposta de que cuida o art. 58 da mesma lei. Disponível em: http://www.tse.jus.br/legislacao-tse/res/2001/RES209512001.htm

BRASIL. Tribunal Superior Eleitoral. Exceção n⿳ 47122, Acórdão, Relator(a) Min. Maria Thereza de Assis Moura, Publicação: DJE - Diário da justiça eletrônica, Tomo 201, Data 22/10/2015, Página 29/30.

CORTE INTERAMERICANA DE DIREITOS HUMANOS. Caso Castillo Petruzzi y otros Vs Perú. Sentencia de 30 de mayo de 1999. Fondo,

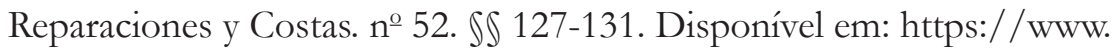
corteidh.or.cr/docs/casos/articulos/seriec_52_esp.pdf

CORTE INTERAMERICANA DE DIREITOS HUMANOS. Caso Herrera Ulloa Vs Costa Rica. Sentencia de 2 de julio de 2004. Excepciones Preliminares, Fondo, Reparaciones y Costas. no 107. Disponível: http:/ /www. corteidh.or.cr/docs/casos/articulos/seriec_107_esp.pdf

CORTE INTERAMERICANA DE DIREITOS HUMANOS. Caso Palamare Iribarne Vs Chile. Sentencia de 22 de noviembre de 2005. Fondo, Reparaciones y Costas. $\mathrm{n}^{\circ} 135$. Disponível em: http://corteidh.or.cr/docs/ casos/articulos/seriec_135_esp.pdf

CORTE INTERAMERICANA DE DIREITOS HUMANOS. Caso Apitz Barbera y otros ("Corte Primeira de lo Contencioso Administrativo") vs Venezuela. Sentencia de 5 de agosto de 2008. Excepción Preliminar, Fondo, Reparaciones y Costas, no 182 . Disponível em: http://www.corteidh.or.cr/ docs/casos/articulos/seriec_182_esp.pdf

CORTE INTERAMERICANA DE DIREITOS HUMANOS. Caso Usón Ramírez Vs Venezuela. Sentencia de 30 de noviembre de 2009. Excepción Preliminar, Fondo, Reparaciones y Costas. no 207. Disponível em: http:/ / www.corteidh.or.cr/docs/casos/articulos/seriec_207_esp.pdf

CORTE INTERAMERICANA DE DIREITOS HUMANOS. Caso Atala Riffo y Niñas Vs Chile. Sentencia de 24 de febrero de 2012. Fondo, reparaciones y costas. $\mathrm{n}^{\mathrm{o}} 239$. Disponível em: http://corteidh.or.cr/docs/casos/ articulos/seriec_239_esp.pdf 
CORTE INTERAMERICANA DE DIREITOS HUMANOS. Caso Acosta y Otros Vs Nicaragua. Sentencia de 25 de marzo de 2017. Excepciones preliminares, Fondo, Reparaciones y Costas. nํ3ㄱ. Disponível em: http://www. corteidh.or.cr/docs/casos/articulos/seriec_334_esp.pdf

CORTE INTERAMERICANA DE DIREITOS HUMANOS. Caso V.R.P., V.P.C. y otros Vs Nicaragua. Sentencia de 8 de marzo de 2018. Excepciones Preliminares, Fondo, Reparaciones y Costas. no 350. Disponível em: https://www.corteidh.or.cr/docs/casos/articulos/seriec_350_esp.pdf

ORGANIZAÇÃO DOS ESTADOS AMERICANOS. Convenção Americana de Direitos Humanos. 22 de novembro de 1969. Disponível em: https://www.cidh.oas.org/basicos/portugues/c.convencao_americana.htm.

Amanda Guimarães da Cunha - Especialista em Direito Eleitoral e em Ciências Penais, Bacharela em Direito pela Universidade do Vale do Itajaí (UNIVALI). Membro Pesquisadora do Observatório do Sistema Interamericano de Direitos Humanos (UNIVALI) nas áreas de direito eleitoral, direito sancionador, direitos humanos e temáticas de gênero. E-mail: amandagdacunha@gmail.com Orcid: https://orcid.org/0000-0001-5458-4724.

Eneida Desiree Salgado - Doutora e Mestra em Direito do Estado pela Universidade Federal do Paraná (UFPR). Estágio de pós-doutoramento junto ao Instituto de Investigaciones Jurídicas da Universidad Nacional Autónoma de México. Estágio de pós-doutoramento junto ao Programa de Pós-Graduação em Ciência Política da UFPR. Professora do Departamento de Direito Público, do Programa de Pós-Graduação em Direito e Pesquisadora líder do Núcleo de Investigações Constitucionais da UFPR. Coordenadora do Política Por/De/Para Mulheres. Visiting scholar no Jack W. Peltason Center for the Study of Democracy (CSD) na University of California, Irvine (2020). Membro fundadora do Instituto Brasileiro de Direito Parlamentar. E-mail: desisalg@gmail.com Orcid: https://orcid.org/0000-0003-0573-5033. 